\title{
Peran Komunitas Dalam Meningkatkan Literasi Dan Inklusi Keuangan Syariah
}

\author{
Galih Tegar Febrianto \\ Politeknik Elektronika Negeri Surabaya \\ Kampus ITS, Jl. Raya ITS, Keputih, Kec. Sukolilo, Kota Surabaya \\ anongtf26@gmail.com \\ Faza Ghulam Ahmad \\ Politeknik Elektronika Negeri Surabaya \\ Kampus ITS, Jl. Raya ITS, Keputih, Kec. Sukolilo, Kota Surabaya \\ fazaghulam@gmail.com

\begin{abstract}
Imamul Arifin
Politeknik Elektronika Negeri Surabaya

Kampus ITS, Jl. Raya ITS, Keputih, Kec. Sukolilo, Kota Surabaya imamul@pens.ac.id
\end{abstract}

\begin{abstract}
Abstrak
Literasi dan inklusi keuangan merupakan suatu derajat yang menunjukan bagaimana masyarakat telah mengerti dan menggunakan produk keuangan dengan optimal. Kenyataannya menunjukan bahwa tingkat literasi dan inklusi keuangan Indonesia masih berada di angka 38\%. Itu artinya hanya 38 orang dari 100 orang yang mampu mengetahui dan memahami produk keuangan dengan baik. Di satu sisi, komunitas telah dikenal sebagai wadah yang mempersatukan masyarakat Indonesia yang besifat komunal. Di sini komunitas hadir untuk menjadi mediator serta pemercepat peningkatan literasi dan inkluasi keuangan. Potensi yang dimiliki oleh komunitas setidaknya mencakup (1) membantu menopang Strategi
\end{abstract}


J-Al-Mutharahah : Vol. 17 No. 1 Januari-Juni 2020

Nasional Literasi Keuangan Indonesia; (2) mediator pengembangan literasi dan inklusi keuangan syariah melalui modal sosial; dan (3) membuka kerja sama dengan budaya partisipatori.

\section{Abstract}

Financial literacy and inclusion is a degree that shows how the public has understood and used financial products optimally. The reality shows that the level of literacy and financial inclusion in Indonesia is still at 38\%. That means only 38 people out of 100 people can know and understand financial products well. On the other hand, the community has been known as a forum that unites communal Indonesians. Here the community is become a mediator and accelerates the increase in financial literacy and inclusion. Potential owned by the community at least include (1) helping to sustain the National Strategy on Financial Literacy in Indonesia; (2) mediators for the development of Islamic financial literacy and inclusion through social capital; and (3) open cooperation with participatory culture.

\section{Kata Kunci: Literasi Keuangan, Penyetaraan, Komunitas Keywords: Financial Literacy; Inclusion; Community}

\section{A. PENDAHULUAN}

Indonesia merupakan negara dengan jumlah penduduk terbesar keempat di dunia. Tercatat pada tahun 2020 jumlah penduduk Indonesia sebanyak 273 juta jiwa. ${ }^{1}$ Dengan laju pertumbuhan penduduk sebesar $1,07 \%$ tiap tahunnya tentu saja pertambahan ini diikuti dengan peningkatan pendapatan negara yang ditunjukkan melalui Produk Domestik Bruto (PDB) masyarakat. Dengan meningkatnya Produk Domestik Bruto Indonesia, jumlah uang yang beredar juga semakin meningkat. Hal ini menandakan bahwa transaksi keuangan yang dilakukan

\footnotetext{
${ }^{1}$ Meter, "Indonesia Population (2020) - Worldometer."
} 
J-Al-Mutharahah : Vol. 17 No. 1 Januari-Juni 2020

masyarakat baik untuk kebutuhan pribadi maupun usaha juga semakin bertambah.

Survei nasional yang dilakukan Otoritas Jasa Keuangan tahun 2019 mengenai literasi keuangan yang dilakukan pada tahun 2019 menunjukkan indeks literasi keuangan mencapai $38,03 \%$ dan indeks inklusi keuangan 76,19\%. Angka ini meningkat 8,33\% terhadap peningkatan literasi keuangan dan 8,39\% terhadap peningkatan akses produk dan layanan jasa keuangan (inklusi keuangan) dibanding hasil survei sebelumnya yang dilakukan pada tahun $2016 .^{2}$

Kegiatan literasi merupakan indikator penting untuk meningatkan kompetensi dan pembangunan ekonomi. Dalam hal ini kualitas sumber daya manusia perlu ditingkatkan. Bahkan perintah untuk literasi sudah ada dalam wahyu pertama yang diturunkan Allah SWT kepada Nabi Muhammad yaitu surat Al Alaq 1-5.

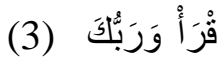

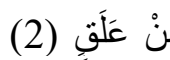

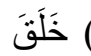

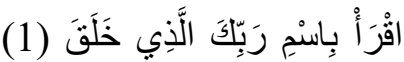 الْأَكْرَمُمُ

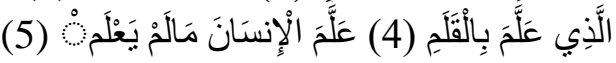

Artinya: "Bacalah dengan mnyebut nama Tuhanmu yang telah menciptakan. Yang telah menciptakan manusia dari segumpal darah. Bacalah dengan nama Tuhanmu yang maha mulia. Yang telah mengajarkan manusia dengan perantara membaca dan menulis".

Peningkatan literasi masyarakat dapat dilakukan dengan berbagai cara. Di sinilah peran penting komunitas sebagai salah satu upaya meningkatkan literasi ekonomi masyarakat. Komunitas disini bertujuan untuk memberi wadah masyarakat untuk berkembang sekaligus menjadi sebagai upaya peningkatan indeks literasi keuangan dan indeks inklusi

\footnotetext{
2 Otoritas Jasa Keuangan, "Siaran Pers Survei OJK 2019: Indeks Literasi Dan Inklusi Keuangan Meningkat."
} 
J-Al-Mutharahah : Vol. 17 No. 1 Januari-Juni 2020

keuangan Indonesia.

\section{B. METODE PENELITIAN}

Dalam studi kali ini, kami menggunakan metode Systematic Literature Review (SLR). Metode ini bisa dikatakan tepat untuk mendapatkan perpaduan berbagai literatur akademik yang akurat ${ }^{3}$. Kami mengumpulkan berbagai sumber literatur dari Google Scholar dan Mendeley untuk mencari jurnal, artikel, penelitian, maupun buku yang berhubungan dengan penelitian yang kami lakukan. Setelah semua bahan literatur didapat, kami menarik kesimpulan serta menyusun semua bahan menjadi artikel yang sistematis.

\section{PEMBAHASAN}

\section{Literasi Keuangan}

literasi keuangan menurut Organisation for Economic Co-operation and Development(OECD) dapat diartikan sebagai kemampuan untuk memahami dan mengetahui konsep dan risiko keuangan, keterampilan mengenai keuangan, serta menggunakan pengetahuan dan pemahaman yang bertujuan untuk meningkatkan kesejahteraan keuangan baik individu maupun masyarakat.4

Literasi keuangan merupakan elemen penting bagi pertumbuhan ekonomi negara karena berdampak langsung kepada masyarakat. Dampak yang dimaksud adalah tinggi rendahnya tingkat literasi keuangan masyarakat akan sejalan dengan tinggi rendahnya penggunaan produk dan jasa keuangan. Jika penggunaan produk dan jasa keuangan meningkat maka potensi transaksi keuangan yang terjadi akan meningkat pula yang akan berdampak pada pertumbuhan

\footnotetext{
${ }^{3}$ Chalkiadaki, "A Systematic Literature Review of 21st Century Skills and Competencies in Primary Education."

${ }^{4}$ OECD, PISA 2015 Assessment and Analytical Framework: Science, Reading, Mathematic and Financial Literacy,.
} 
ekonomi secara keseluruhan atau menciptakan pemerataan pendapatan masyarakat. Oleh karena itu, literasi keuangan sudah seharusnya dimiliki setiap individu agar mereka dapat merencanakan dan mengelola keuangan dengan baik.

Namun faktanya Survei Nasional Literasi Keuangan tahun 2016 yang dilakukan oleh OJK menunjukkan bahwa kondisi literasi keuangan yang ada di Indonesia masih jauh dari kata layak. ${ }^{5}$ Data tersebut mencata bahwa tingkat literasi keuangan Indonesia hanya sebesar 29,7\% yang artinya dari 100 orang hanya sekitar 30 orang yang memiliki pengetahuan, keterampilan, dan kepercayaan yang memdai mengenaik produk dan layanan keuangan (well literate).

Literasi keuangan memiliki tingkat-tingkat yang berfungsi untuk mengukur seberapa baik literasi keuangan seseorang.Menurut Otoritas Jasa Keuangan tingkat literasi keuangan seseorang dapat dibagi menjadi 4 tingkat yaitu:

a) Well Literate

Seseorang dapat dikatakan telah memasuki tahap ini apabila mereka memiliki pengetahuan dan keyakinan mengenai lembaga jasa keuangan, produk keuangan yang dihasilkan, dan jasa keuangan yang ditawarkan. Selain itu dapat diklasifikasikan juga bahwa seseorang yang telah memiliki keterampilan dalam memakai produk dan jasa keuangan dapat dikatakan sebagai well literate.

b) Sufficient Literate

Seseorang yang memiliki pengetahuan dan keyakinan mengenai lembaga jasa keuangan, produk keuangan yang dihasilkan, dan jasa keuangan yang diberikan termasuk pada tahap ini. Tidak menutup kemungkinan juga seseorang yang telah mengetahui

\footnotetext{
5 Otoritas Jasa Keuangan, "Survei Nasional Literasi Dan Inklusi Keuangan
} 2016 (National Literacy and Financial Inclusion Survey 2016)." 
J-Al-Mutharahah : Vol. 17 No. 1 Januari-Juni 2020

fitur, manfaat dan risiko, hak dan kewajiban terkait produk dan jasa keuangan juga termasuk pada tahap ini.

c) Less Literate

Seseorang dikatakan less literate apabila mereka hanya memiliki pengetahuan mengenai lembaga jasa keuangan serta produk dan jasa keuangan yang ditawarkan.

d) Not Literate

Pada tahap ini, seseorang tidak memiliki pengetahuan dan keyakinan apa pun mengenai lembaga jasa keuangan, layanan produk dan jasa keuangan yang ditawarkan, serta tidak memiliki keterampilan dalam menggunakannya.

Literasi keuangan memiliki sebuah variabel yang dapat didefinisikan sebagai ukuran kemampuan seseorang dalam memahami pencatatan keuangan, sikap dalam melakukan transaksi, jasa layanan yang dibutuhkan, nilai tukar uang. Terdapat indikator atau tolok ukur pengetahuan yang dapat menunjukkan seberapa besar tingkat literasi keuangan seseorang, sebagai berikut:

a) Pengetahuan mengenenai nilai barang dan skala prioritas

b) Penganggaran, tabungan, dan pengelolaan uang

c) Pengelolaan kredit

d) Pentingnya asuransi dan perlindungan terhadap risiko

e) Dasar Investasi

f) Perencanaan pension

g) Penggunaan dari belanja dan membandingkan produk yang mana harus pergi mencari saran dan informasi bimbingan, dan dukungan tambahan

h) Bagaimana mengenali potensi konflik atas kegunaan (prioritas)

Berbagai indikator kurangnya angka literasi ekonomi masyarakat diantaranya belum terciptanya pengetahuan dan 
pemahaman mengenai bagaimana memanfaatkan uang yang dimiliki untuk kegiatan yang produktif. Selain itu indikator lain yang dapat ditemukan adalah kurangnya pemahaman mengenai berbagai produk dan layanan jasa keuangan yang ditawarkan oleh lembaga jasa keuangan. Padahal jika dipelajari lebih mendalam terdapat banyak manfaat yang seharusnya didapatkan oleh masyarakat yang akan membawa mereka menuju kesejahteraan. Seperti yang difirmankan oleh Allah SWT dalam surat Al Jumu'ah ayat 10:

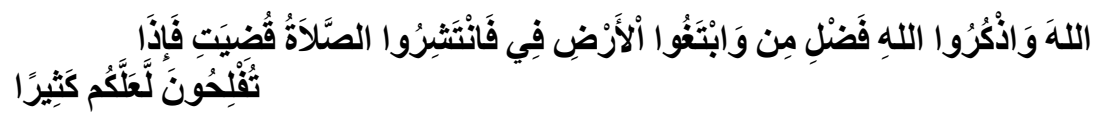

Artinya: "Apabila telah ditunaikan shalat, maka bertebaranlah kamu di muka bumi; dan carilah karunia Allah dan ingatlah Allah banyak-banyak supaya kamu beruntung."

Dalam konteks ini Al Qur'an telah menjelaskan prinsipprinsip ekonomi yang semua cabang-cabang kembali kepadanya. Hal itu karena masalah-masalah ekonomi kembali kepada dua prinsip yaitu kecerdasan dalam mencari harta dan kecerdasan dalam membelanjakannya pada tempat-tempatnya.

\section{Inklusi Keuangan}

Definisi inklusi keuangan adalah setiap individu atau bisnis yang mempuanyai akses untuk menggunakan produk dan jasa keuangan. Setiap lapisan masyarakat tentunya diharapkan memiliki akses yang setara dalam penggunaan uang dan dapat memanfaatkan setiap layanan produk dan jasa keuangan dengan optimal.

Berdasarkan data Global Findex(2010), mereka yang memiliki keleluasaan akses dengan jasa keuangan di Indonesia terhitung hanya sebesar 36 persen saja ${ }^{6}$. Sisanya sekitar 64 persen masyarakat Indonesia masih belum memiliki akses dengan jasa keuangan apapun atau dapat dikatakan

\footnotetext{
${ }^{6}$ Klapper, Leora; Singer, Dorothi; Ansar, "The Global Findex Database.”
} 
unbankable. Hal ini tentu menandakan bahwa upaya yang harus dilakukan pemerintah dan masyarakat masih banyak untuk mengangkat Indonesia menjadi negara ekonomi inklusif serta menghilangkan adanya ketimpangan ekonomi pada lapisan masyarakat.

Inklusi keuangan merupakan salah satu cara yang dapat dilakukan untuk menurunkan tingkat kemiskinan dan kesenjangan ekonomi yang ada di masyarakat. Upaya ini telah diinisiasi oleh Otoritas Jasa Keuangan sejak bulan Oktober 2016 dalam rangka mengurangi ketimpangan ekonomi. Bank Indonesia menyatakan bahwa tidak ada definisi yang baku dari ekonomi inklusif. Namun ekonomi inklusif dapat juga diartikan sebagai suatu keadaan dimana seluruh lapisan masyarakat telah mendapatkan dan menikmati layanan produk dan jasa keuangan secara efektif dan efisien. Selain itu ekonomi inklusif juga dapat dikaitkan dengan banyaknya nasabah dalam suatu bank. Hal ini juga tidak salah, mengingat bank merupakan salah satu media pelayanan dan akses keuangan yang dapat memberikan layanan keuangan secara praktis.

Dalam perkembangannya, upaya dalam meningkatkan inklusi keuangan tidak hanya sebatas pengembangan produk dan layanan jasa keuangan tetapi juga meliputi empat elemen lain yang tidak kalah penting yaitu perluasan akses keuangan, ketersediaan layanan produk dan jasa keuangan dan penggunaannya, serta pengingkatan kualitas penggunaan produk dan layanan jasa keuangan maupun kualitas produk dan layanan jasa keuangan itu sendiri.

Jika dilihat dari hasil Survei Nasional Literasi Keuangan tahun 2019 yang dilakukan oleh OJK menunjukkan bahwa indeks inklusi keuangan masyarakat Indonesia relatif tinggi dibandingkan dengan indeks literasinya. Pada tahun 2019 OJK mencatat 76,19\% masyarakat Indonesia telah memiliki akses lembaga jasa keuangan formal. Namun inklusi keuangan dapat dikatakan terwujud jika seluruh masyarakat Indonesia dapat 
mengakses layanan keuangan dengan mudah. Efek yang diharapkan tentunya meningkatkan kemampuan ekonomi, berkurangnya kemiskinan serta kesenjangan sosial, dan meningkatkan kesejahteraan masyarakat.

Selain efek diatas inklusi keuangan juga memiliki banyak manfaat. Bank dunia menyebutkan bahwa dengan meningkatnya inklusi keuangan sebesar satu persen saja dapat meningkatkan pertumbuhan ekonomi sebesar 0.03 persen. Berbagai manfaat inklusi keuangan dalam bentuk lain seperti bertambahnya lapangan pekerjaan, menurunkan tingkat kemiskinan, hingga mengurangi kesenjangan sosial. Oleh karena itu diharapkan dengan adanya inklusi keuangan maka setiap lapisan masyarakat memiliki akses yang setara dalam penggunaan uang sehingga akan mendapatkan manfaat yang sama di setiap layanan dengan baik.

\section{Ekonomi Syariah}

Ekonomi syariah adalah ilmu pengetahuan yang bertujuan untuk melihat, menganalisa, yang nantinya akan menjadi penyelesaian permasalahan yang berkaitan dengan ekonomi dengan cara yang diatur dalam Islam, yaitu harus berdasarkan Al Qur'an dan sunnah Rasulullah. Terdapat dua pokok yang menjadi landasan hukum sistem ekonomi syariah yaitu Al Qur'an dan sunnah Rasulullah. Segala hukum yang bersumber dari kedua landasan pokok tersebut secara konsep dan prinsip adalah tetap dan tidak dapat berubah kapan pun dan dimana pun (Anto 2003).

Dalam pelaksanaannya ekonomi syariah memiliki prinsip yang harus dijalankan sebagai berikut7:

a) Segala sesuatu termasuk sumber daya dianggap sebagai pemberian atau titipan dari Allah SWT kepada manusia

b) Kepemilikan pribadi diakui Islam selama dalam batasanbatasan tertentu.

\footnotetext{
${ }^{7}$ Sudarsono, Konsep Ekonomi Islam : Suatu Pengantar.
} 
c) Kerja sama menjadi kekuatan penggerak utama dalam ekonomi syariah.

d) Akumulasi kekayaan yang hanya dikuasai oleh segelintir orang tidak diperbolehkan dalam ekonomi syariah

e) Ekonomi syariah menjamin pemilikan masyarakt dan penggunaannya direncanakan tidak untuk segelintir orang saja.

f) Seorang muslim harus takut kepada Allah SWT beserta yaumul hisab di akhirat nanti.

g) Zakat yang dibayarkan harus atas kekayaan yang telah memenuhi batas (nisab).

h) Segala bentuk riba dilarang di dalam Islam.

Menghindari melakukan penimbunan atau dalam bahasa arab biasa disebur al-ihtikar. Penimbunan dapat didefinisikan sebagai membeli sebuah barang perniagaan dengan tujuan untuk menyimpannya dalam kurun waktu yang lama sehingga nantinya barang tersebut dinyatakan sebagai barang yang langka karena ketersediaannya yang terbatas namun permintaannya melebihi ketersediaan sehingga berharga mahal.

Tidak melakukan monopoli. Monopoli merupakan situasi dimana sekurang-kurangnya sepertiga pengadaan barang perdagangan tertentu hanya dikuasai oleh satu pihak atau kelompok sehingga harga barang tersebut dapat dikendalikan oleh pihak yang menguasai. Dengan melakukan monopoli maka hanya pihak tertentu saja yang diuntungkan yakni pihak yang menguasai. Sedangkan pihak lain hanya menerima hasil yang tidak sebesar pihak penguasa. Kegiatan ini merupakan salah satu hal yang dilarang dalam Islam.

Menghindari jual beli yang diharamkan oleh Islam. Allah SWT sangat meridhai segala sesuatu dalam jual beli yang sesuai dengan syariat Islam, adil, halal, dan tidak merugikan dan menguntungkan sebelah pihak. Karena sesungguhnya 
segala sesuatu yang mengandung unsur kemungkaran dan kebatilan didalamnya maka hukumnya adalah haram.

Dalam pengamalannya tentu saja ekonomi syariah akan mendatangkan manfaat yang besar bagi siapa saja yang mengamalkannya. Manfaaat tersebut antara lain:

a) Terwujudnya integritas seorang muslim yang kaffah atau tidak setengah-setengah atau menjadi muslim yang sesungguhnya.

b) Menerapkan dan mengamalkan ekonomi syariah melalui lembaga keuangan berasaskan Islam seperti bank, pegadaian, asuransi, akan memperoleh keuntungan dunia yakni melalui bagi hasil maupun keuntungan akhirat yakni terbebas dari segala unsur riba yang dimurkai oleh Allah.

c) Mengamalkan ekonomi syariah melalui lembaga keuangan syariah dihitung sebagai dukungan untuk kemajuan lembaga ekonomi umat Islam. Karena semua dana yang ada pada lembaga keuangan syariah hanya diperbolehkan untuk disalurkan kepada usaha yang halal.

d) Mengamalkan ekonomi syariah berarti ikut berpartisipasi dalam mengamalkan amar ma'ruf nahi munkar.

e) Menjalankan praktik ekonomi syariah akan dihitung juga sebagai nilai ibadah, karena telah mengamalkan apa yang dianjurkan dan yang dilarang oleh Allah.

f) Mengamalkan ekonomi syariah dengan membuka tabungan dan deposito atau menjadi nasabah berarti ikut serta mendukung upaya pemberdayaan ekonomi umat. Karena dana yang terkumpul akan dihimpun dan disalurkan melalui sekor perdagangan yang riil.

Tujuan ekonomi syariah adalah mewujudkan kesejahteraan manusia dan menciptakan keseimbangan 
ekonomi dalam masyarakat. Namun tujuan ini harus dicapai dengan selalu mengikuti cara yang baik dan terhormat yang tentu saja harus bersumber dari Al Qur'an dan sunnah sebagaimana Allah SWT berfirman dalam suran An Nisa 38:

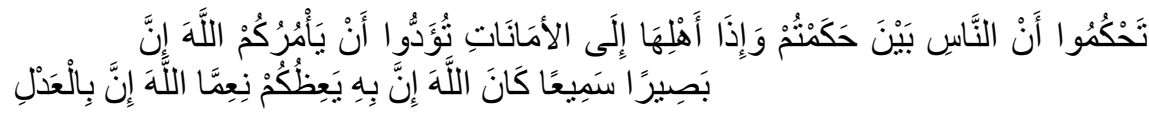

Artinya: "Sesungguhnya Allah menyuruh kamu menyampaikan amanat kepada yang berhak menerimanya, dan (menyuruh kamu) apabila menetapkan hukum di antara manusia supaya kamu menetapkan dengan adil. Sesungguhnya Allah memberi pengajaran yang sebaik-baiknya kepadamu. Sesungguhnya Allah adalah Maha mendengar lagi Maha Melihat."

Untuk mencapai tujuan tersebut dibutuhkan sumber daya manusia yang mendalami fiqih muamalah, qawaid fiqhiyyah, qawaid ushuliyyah, dan sejenisnya agar terhindar dari kesalahpahaman yang dapat menjerumuskan. Salah satu problem ekonomi syariah saat ini adalah bahwa ia dikembangkan oleh kalangan yang belum sempurna pemahamannya sehingga dibutuhkan sebuah komunitas yang kredibel dan terpercaya untuk mengatasi masalah tersebut.

\section{Komunitas dan Strategi Nasional Literasi Keuangan Indonesia}

Komunitas secara tradisional bisa diartikan sebagai kelompok sosial dari beberapa organisme yang saling berbagi lingkungan dan memiliki ketertarikan yang sama. Dalam komunitas manusia, setiap individu di dalamnya bisa saja memiliki kepercayaan, maksud sumber daya, kebutuhan, preferensi, risiko dan kondisi-kondisi lain yang serupa. Berdasarkan yang dikatakan Kertajaya(2008)8, komunitas diartikan sebagai sekelompok orang yang saling peduli antar

${ }^{8}$ Kertajaya, Arti Komunitas. 
sesama lebih dari seharusnya yang menimbulkan terjadinya relasi pribadi yang erat antar para anggota komunitas tersebut karena kesamaan interest atau values.

Sedangkan jika ditinjau dari sisi sosiologi, sebuah komunitas adalah kelompok sosial dari beberapa organisme yang saling berbagi lingkungan dan pada umumnya memiliki ketertarikan yang sama. Delobelle (2008) mendefinisikan suatu komunitas sebagai group dari beberapa orang yang berbagi minat yang sama, yang terbentuk dari 4 faktor ${ }^{9}$, yaitu:

a) Keinginan berbagi (sharing) dan Komunikasi, dimana para anggota selalu tolong-menolong satu sama lain.

b) Tempat berkumpul atau bertemu yang disepakati bersama.

c) Kebiasaan, dimana orang-orang di dalam komunitas datang secara periodic, dan

d) Influencer, merintis sesuatu hal serta melibatkan anggota-anggota selanjutnya.

Di luar pengertian komunitas, Strategi Nasional Literasi Keuangan Indonesia(SNLKI) pertama kali diluncurkan tanggal 19 November 2013 merupakan sekumpulan petunjuk bagi OJK maupun industri keuangan dalam mengimplementasikan Peraturan OJK Nomor 1/POJK.07/2013 tentang Perlindungan Konsumen Sektor Jasa Keuangan khususnya yang terkait dengan penyelenggaraan kegiatan dalam rangka peningkatan literasi keuangan di Indonesia. Pendekatan dalam melakukan kegiatan literasi dan inklusi keuangan harus berdasarkan pada:

a) Pendekatan Geografis

Pendekatan dilakukan dengan memanfaatkan kelebihan daerah masing-masing dikombinasikan dengan tingkat literasi dan inklusi daerah setempat.

a) Pendekatan Sasaran

Pendekatan dengan mengarah kepada suatu kelompok tertentu seperti ibu-ibu, pekerja kantoran, dll.

${ }^{9}$ Delobelle, "Corporate Community Management." 
b) Pendekatan Sektoral

Pendekatan melalui aspek-aspek pembentuk indeks literasi dan inklusi keuangan seperti perbankan, pasar modal, pegadaian, dll.

SNLKI (Revisit 2017) mempunyai 3 program strategis yang dirancang berdasarkan pengertian bahwa Pertama, konsep dasar literasi keuangan bukan hanya didasarkan pada tiga aspek literasi keuangan yaitu pengetahuan, keterampilan, dan keyakinan, melainkan meliputi pula aspek sikap dan perilaku. Kedua, dalam kenyataannya, literasi keuangan sangat berkaitan erat dengan inklusi keuangan sehingga perlu adanya keselarasan dan kesinambungan antara kegiatan literasi keuangan dengan inklusi keuangan. Ketiga, pencapaian strategi literasi dan inklusi keuangan lebih efisien dilakukan secara bersama-sama sehingga tujuan pencapaian literasi keuangan untuk memperluas akses masyarakat ke sektor jasa keuangan dapat dilakukan dengan lebih optimal. Ketiga program strategis terebut ialah:

a) Cakap Keuangan

Kecakapan keuangan terbentuk dari beberapa komponen yaitu pengetahuan, keterampilan dan keyakinan.

b) Sikap dan Perilaku Keuangan Bijak

Sikap keuangan yang bijak diawali dengan adanya tujuan keuangan yang dimiliki oleh seseorang. Tujuan keuangan tersebut merupakan wadah bagaimana seseorang dapat merencanakan dan mengelola keuangan dengan baik dalam jangka pendek maupun panjang.

c) Akses Keuangan

Kecakapan keuangan yang disertai dengan sikap dan perilaku keuangan yang bijak memudahkan masyarakat untuk memanfaatkan lembaga, produk dan layanan jasa keuangan yang sesuai dengan kebutuhan dan kemampuan.

Dari uraian di atas, komunitas mampu memenuhi beberapa hal. Pertama, komunitas merupakan alat yang baik 
untuk melakukan pendekatan literasi dan inklusi keuangan dengan pendekatan sasaran. Serta tidak menutup kemungkinan pendekatan secara geografis dan sektoral. Sebagai contoh adalah komunitas Investor Saham Pemula yang tersebar di berbagai daerah menjadi komunitas lokal seperti Investor Saham Pemula Surabaya, dsb. Kedua, komunitas sangat cocok untuk mengimplementasikan program strategis sikap dan perilaku keuangan bijak. Data dari OJK (2017) menunjukan saran dari teman mempengaruhi 30\% keputusan kita dalam hal keuangan. Sebagaimana faktor yang komunitas miliki, yaitu keinginan untuk berbagi dan influencer yang mampu mempengaruhi cara pandang serta pemikiran seseorang dalam menyusun strategi keuangannya. Memiliki lingkungan yang sangat supportive dalam hal keuangan membuat kita menjadi lebih bijak dalam mengatur sikap dan perlaku keuangan.

\section{Modal Sosial dalam Komunitas}

Modal sosial diartikan sebagai pengorbanan individu baik berupa waktu, tenaga, ataupun konsumsi yang dilakukan sebagai upaya untuk meningkatkan kerjasama dengan orang lain ${ }^{10}$. Selain itu, Felicio et.al. menjelaskan bahwa modal sosial merupakan solidaritas, kepercayaan diri, dan kemampuan memfasilitasi dalam menjalankan suatu bisnis, yang menjadi faktor dari hubungan sosial antara keluarga, teman, rekan kerja, atau yang lainnya ${ }^{11}$. Dari kedua pemaparan tersebut, dapat disimpulkan bahwa modal sosial adalah sikap sesorang atau kelompok yang mempercayai suatu pemahaman, norma, aturan dan harapan mengenai perannya yang mengikat dalam hubungan interpersonal dan keanggotaan, serta menjadi penghubung jaringan sosial yang diimplementasikan dalam

\footnotetext{
10 Oxoby, "Understanding Social Inclusion, Social Cohesion, and Social Capital."

11 Felício, Couto, and Caiado, "Human Capital, Social Capital and Organizational Performance."
} 
suatu aksi kolektif. Modal sosial inilah yang menjadi pondasi utama dalam komunitas.

Sesuai penelitian yang dilakukan Saputra, menghasilkan kesimpulan bahwa modal sosial berperan secara signifikan sebagai mediator antara literasi keuangan dan inklusi keuangan ${ }^{12}$. Selain itu juga penelitian tersebut mendapat temuan bahwa dampak literasi keuangan pada inklusi keuangan akan meningkat jika terdapat peran dari modal sosial, hal ini berarti efek langsung literasi keuangan pada inklusi keuangan dapat dikatakan rendah.

Hal tersebut membuktikan bahwa komunitas sangat berdampak pada peningkatan literasi dan inklusi keuangan. Ditambah lagi dengan atribut syariah yang diusung oleh komunitas, menjadikan komunitas merupakan tonggak utama dalam menjalankan program strategis cakap keuangan serta kesadaran untuk terus belajar. Dimana kecakapan yang didapat bukan hanya di bidang finance melainkan juga pemahaman akan pasar keuangan syariah.

\section{Participatory Culture dan Komunitas Online}

Istilah participatory culture atau budaya partisipatori atau partisipatif memang masih asing di telinga kita, pengertian budaya ini agak bertentangan dengan pengertian budaya konsumen dimana terdapat pembagian yang jelas antara produsen dengan konsumen. Pada perkembangannya, dalam budaya partisipatori ini user atau anggota dalam komunitas online bertindak tidak hanya sebagai pengguna atau konsumen, akan tetapi sekaligus juga sebagai kontributor bahkan produser dan dapat mempublikasikan

12 Saputra and Dewi, "Peran Modal Sosial Sebagai Mediator Literasi Keuangan Dan Inklusi Keuangan Pada Kaum Muda Di Indonesia (Studi Kasus Pada Komunitas Investor Saham Pemula)." 
media tersebut dengan mudah. Bentuk partisipatori menurut Jenkins dapat dinyatakan dengan 4 aspek $^{13}$ :

a) Affiliations, meliputi keanggotaan, sifat formal atau informal, dalam menjalin komunikasi online terpusat.

b) Expressions, kreativitas baru yang tercipta dalam komunitas.

c) Collaborative Problem-solving, melibatkan bekerja bersama tim untuk menyelesaikan suatu tugas dan mengembangkan pengetahuan.

d) Circulations, membentuk aliran media.

Adapun sifat-sifat yang menyatakan budaya partisipatori adalah sebagai berikut:

a) Memberikan kemudahan akses untuk berekspresi dan pengembangan kepentingan bersama.

b) Dukungan yang kuat dalam berkarya dan berbagi kreasi dengan yang lainnya.

c) Membuka peluang pengembangan konsep mentor antar anggota.

d) Anggota meyakini kontribusinya akan berarti bagi yang lainnya.

e) Memperkuat hubungan sosial sesama anggota, rasa menghargai karya.

f) Tidak ada tekanan untuk berkontribusi, akan tetapi tetap memberi kesempatan dan dorongan untuk berkontribusi.

Kita sudah mengetahui tentang komunitas secara tradisional. Seiring berkembangnya teknologi digital, kini komunitas juga merambah ke dalam dunia maya atau yang biasa disebut komunitas online. Dalam komunitas online, individu-individu dari berbagai organisme seakan-akan hadir duduk bersama saling mengekpresikan diri dan mengembangkan "pengalaman" bersama, dimana teknologi

${ }^{13}$ Jenkins et al., "Confronting the Challenges of Participatory Culture: Media Education for the 21 St Century." 
J-Al-Mutharahah : Vol. 17 No. 1 Januari-Juni 2020

komputer dan internet menjadi infrastruktur dari dibangunnya suatu ranah virtual bagi komunitas maya. Persamaan antara komunitas virtual dengan komunitas fisik/umum menurut Rajaraman adalah seperti tetangga, klub, organisasi, tetapi orang-orang tidak bertemu (tatap muka secara langsung) ${ }^{14}$. Komunitas virtual menawarkan beberapa cara kepada anggotanya untuk berinteraksi, bekerjasama, ataupun berdagang. Menurut Laudon dan Traver (2003), komunitas online dapat dikelompokkan melalui beberapa cara, salah satunya adalah dengan mengelompokan anggota komunitas berdasarkan kategori tertentu15. Terdapat 5 kategori yang dapat dikelompokkan adalah sebagai berikut:

a) General community, dimana komunitas ditujukan untuk umum menawarkan kesempatan pada anggotanya untuk saling berinteraksi secara umum dengan siapa saja dari anggota komunitas dengan topik bebas. Sehingga anggota akan dapat menemukan ratusan topik-topik diskusi yang sangat beragam dan diskusi grup para anggota yang men-shareide-ide, cerita, informasi, atau pengetahuannya.

b) Practice communities atau komunitas yang menawarkan anggotanya dapat melakukan focus group discussion secara online, diskusi, saling menolong, dan memberikan sharing pengetahuan antar anggota. Contohnya komunitas non profit Open source yang mengembangkan dengan melibatka ribuan programmer yang membuat dan mengembangkan kode-kode komputer untuk sistem operasi linux dan berbagi hasil secara cuma-cuma dengan web Linux dengan web www[dot]linux[dot]org.

\footnotetext{
14 RAJARAMAN, "Introduction To Information Technology." 15 Laudon and Laudon, Management Information Systems Managing the Digital Firm.
} 
c) Interest communities, komunitas diskusi berdasarkan pada berbagai topik yang spesifik yang sesuai dengan minat atau ketertarikan dan masing-massing anggotanya, contohnya seperti komunitas pecinta alam, kapal, kuda, kesehatan.

d) Affinity communities atau komunitas berdasarkan kesamaan identitas anggotanya atau kelompok.

e) Sponsored communities, jenis komunitas yang dibangun misal oleh pemerintah, perusahaan dengan orientasi non-profit ataupun

Budaya partisipatori ini sangat sejalan dengan perkembangan komunitas online dimana terdapat banyak peluang-peluang baru yang tumbuh dalam banyak aspek dibandingkan perkembangannya dalam media tradisional. Dengan budaya partisipatori ini juga menjadikan komunitas online mampu menjadi jalan untuk program strategis SNLKI bagian akses keuangan. Dengan kebebasan partisipatori, lembaga keuangan bisa menjalin affiliasi dengan komunitaskomunitas yang ada. Sehingga anggota komunitas bisa lebih mudah menjangkau layanan maupun produk keuangan yang tersedia di Indonesia. Selain lembaga keuangan, melalui prinsip partisipatori menjadikan komunitas online lebih terbuka dengan kounitas ataupun lembaga syariah lainnya. Sehingga mendorong anggota untuk mengambil keputusan dengan mantap dari sisi profitabilitas maupun dari sisi syari.

\section{KESIMPULAN}

Dengan kelebihan-kelebihan yang dimililiki komunitas syariah sebagai bagian tak terpisahkan dari sistem sosial masyarakat Muslim di Indonesia, maka komunitas sangat berpotensi untuk memainkan perannya dalam mengembangakan literasi dan inklusi keuangan syariah di Indonesia. Potensi yang dimiliki oleh komunitas setidaknya mencakup (1)membantu menopang Strategi Nasional Literasi 
J-Al-Mutharahah : Vol. 17 No. 1 Januari-Juni 2020

Keuangan Indonesia; (2)mediator pengembangan literasi dan inklusi keuangan syariah melalui modal sosial; dan (3) membuka kerja sama dengan budaya partisipatori.

\section{REFERENSI}

Anto, MB Hendrie; 2003. "Pengantar Ekonomika Mikro Islam." http://library.sebi.ac.id/?p=show_detail\&id=519.

Delobelle, Vanina. 2008. "Corporate Community Management." 2008. https://www.slideshare.net/vaninadelobelle/corporatecommunity-management-407304.

Felício, J. Augusto, Eduardo Couto, and Jorge Caiado. 2014. "Human Capital, Social Capital and Organizational Performance." Management Decision. https://doi.org/10.1108/MD-04-20130260.

Jenkins, Henry, Katie Clinton, Ravi Purushotma, Alice J Robison, and Margaret Weigel. n.d. "Confronting the Challenges of Participatory Culture: Media Education for the 21 St Century." Accessed May 8, 2020. www.macfound.org.

Kendall, Jake, Nataliya Mylenko, and Alejandro Ponce. 2010. "Measuring Financial Access around the World." Policy Research Working Paper.

Kertajaya, Hermawan. 2008. Arti Komunitas.

OECD. 2016. PISA 2015 Assessment and Analytical Framework: Science, Reading, Mathematic and Financial Literacy,. OECD Publishing. https://doi.org/10.1787/9789264255425-en.

OJK. 2017. "Strategi Nasional Literasi Keuangan Indonesia (Revisit 2017)." Otoritas Jasa Keuangan, 1-99.

Otoritas Jasa Keuangan. n.d. "Siaran Pers Survei OJK 2019: Indeks Literasi Dan Inklusi Keuangan Meningkat."

___ 2016. "Survei Nasional Literasi Dan Inklusi Keuangan 2016 (National Literacy and Financial Inclusion Survey 2016)." Survey Report. 2016. www.ojk.go.id.

Oxoby, Robert. 2009. "Understanding Social Inclusion, Social Cohesion, and Social Capital." International Journal of Social Economics. https://doi.org/10.1108/03068290910996963.

RAJARAMAN, V. 2013. "Introduction To Information Technology." Proceedings of the 9th International CDIO Conference. 
J-Al-Mutharahah : Vol. 17 No. 1 Januari-Juni 2020

https://doi.org/10.1111/j.1462-2920.2011.02610.x.

Saputra, Rachmat Simbara, and Andrieta Shintia Dewi. 2017. "Peran Modal Sosial Sebagai Mediator Literasi Keuangan Dan Inklusi Keuangan Pada Kaum Muda Di Indonesia (Studi Kasus Pada Komunitas Investor Saham Pemula)." Jurnal Manajemen Teori Dan Terapan / Journal of Theory and Applied Management. https://doi.org/10.20473/jmtt.v10i3.3064.

Sudarsono, Heri. n.d. Konsep Ekonomi Islam : Suatu Pengantar. 